\title{
Evaluating Students from a Public School: Mental Health Promotion and Prevention in High School
}

\author{
Carlos Alberto M. Do Nascimento, Luciane F. Jacobi, Marcia P. Botega, \\ Maria Rosa C. Schetinger \\ Universidade Federal de Santa Maria, Santa Maria, Brazil \\ Email: canascimento@ufsm.br, lucianefj8@gmail.com, marcipb@hotmail.com, \\ rmariaschetinger@gmail.com
}

How to cite this paper: Do Nascimento, C.A.M., Jacobi, L.F., Botega, M.P. and Schetinger, M.R.C. (2021) Evaluating Students from a Public School: Mental Health Promotion and Prevention in High School. Open Access Library Journal, 8: e7326.

https://doi.org/10.4236/oalib.1107326

Received: March 18, 2021

Accepted: September 4, 2021

Published: September 7, 2021

Copyright (C) 2021 by author(s) and Open Access Library Inc.

This work is licensed under the Creative Commons Attribution International License (CC BY 4.0).

http://creativecommons.org/licenses/by/4.0/

\begin{abstract}
The aim of the current study is to investigate emotional and mental health changes causing psychiatric distress enough to affect the learning process of high school students. Students from three school years of a federal public school in Santa Maria County-RS-Brazil participated in the study. Ninety-four (94) out of 115 students answered the Self Report Questionnaire-SRQ-20, which is a World Health Organization (WHO) tool used worldwide in primary care level in order to identify Minor Mental or Psychiatric Disorders (MMD/MPD). The total of $32.98 \%$ of the participants recorded sufficient scores in psychological suffering. It is worth encouraging educators' knowledge about mental health, as well as their continuous training through Educational Modules for emotional Promotion, Prevention and Learning, which are contextualized in the science-teaching content, as well as improving students' information level on the subject. School is the strategically privileged territory for these actions, since it is the place where children and adolescents spend most of their time. Thus, it enables acquiring knowledge and empowering mental health promotion skills.
\end{abstract}

\section{Subject Areas}

Psychiatry \& Psychology

\section{Keywords}

Teenagers, Mental Health, Science Education, Preventive Actions

\section{Introduction}

Science education is the appropriate knowledge field for the transit of and inte- 
raction between transversal themes such as health, mainly when it comes to mental health and to how it is inserted in the school environment. Thus, the aim of the current study is to investigate emotional and mental health changes that may predispose high school adolescents enrolled in a federal public school to some psychiatric suffering level able to affect their learning process, as well as to propose Mental Health promotion and prevention actions to be taken in the school environment [1].

Mental Health is a state of well-being that enables children, adolescents and adult individuals to exercise their abilities, to overcome the adversities in life, and to study and/or work in a productive and collaborative way with the community they are inserted in [2].

According to the World Health Organization (WHO), there is not an official definition of Mental Health, since cultural differences, subjective judgments and competing theories affect the way Mental Health is defined. Thus, the main concept of Mental Health lies on the well-being and on the full functioning of individuals and, consequently, of their community. Therefore, mental health is more than just the lack of psychiatric and emotional suffering or even of mental illness. The current study addresses Mental Health among children and adolescents in the school environment [3] [4] [5] [6].

For several reasons, it is difficult to define adolescence in a precise way. Firstly, it is widely known that individuals experience this period in different ways, depending on their physical, emotional and cognitive maturity, as well as on other contingencies. The onset of puberty, which may be considered a clear line of demarcation between childhood and adolescence, does not solve the difficulty in defining it Unicef [7].

According to the World Health Organization (WHO), adolescence is a period in life comprising the age group 10 to 19 years; this criterion is mainly used for statistical and political purposes, since several physical, psychological and behavioral changes take place during this period [4] [5] [6] [8]. Adolescence is a development stage comprising deep transformations, as well as a period of remarkable physical, cognitive, psychological, affective and relational growth.

Thus, it is worth highlighting the model of the Psychosocial Theory of Personality Development by Erik Homburger Erikson (1902-1994)-the Erikson model [9], which proposes eight phases/crises throughout the human life cycle. According to the model, individuals build a life plan, a course, a route that seems to be strongly determined by their childhood and its crises, as well as that presents milestones such as the construction of the basic confidence and of the initiative capacity to form an identity during adolescence and early adulthood. This reference allows estimating the enormous challenges posed to the development of individuals since their birth, as well as estimating the importance of experiences and interactions, mainly in their training and education process [9] [10] [11]. 


\section{Adolescence, School and Mental Health}

The World Health Organization estimates that children and adolescents represent approximately $30 \%$ and $14.2 \%$ of the world population. These populations are susceptible to the global mean prevalence of mental disorders (15.8\%) and these rates tend to increase with aging. Some studies conducted in Brazil recorded rates ranging from $7 \%$ to $12.7 \%$ [12].

Thinking about adolescents' health implies thinking about different ways of living adolescence and of living life. It requires rethinking health and health education practices directed to this significant part of society. Adolescents spend most of the time in the school environment, fact that makes it an important field to investigate and approach health-risk behaviors [4] [5] [6] [13].

It is estimated that millions of children and adolescents present psychological symptoms related to learning, conduct and depression issues; to development, attachment, anxiety and eating disorders; to substance abuse, among others; which are not identified and do not receive proper treatment [5].

The Brazilian Association of Psychiatry (ABP: Associação Brasileira de Psiquiatria) conducted a study in August 2008, which covered 142 counties from all Brazilian regions where 2002 interviews were conducted with mothers who sought some type of mental health care for their children. The study revealed that approximately 12.6\% Brazilian individuals between 6 and 17 years old showed symptoms of significant mental disorders such as depression, anxiety, attention deficit and/or hyperactivity, eating disorders, significant issues concerning alcohol and other psychoactive drugs, conduct issues, and even severe psychoses [5]. Data provided by WHO [4] estimate that suicide is the third cause of death among adolescents, as well as that it is associated with the manifestation of Major Depression, which has effects throughout adulthood [5] [6].

According to the report by WHO on World Health: Mental Health, "public education and awareness campaigns on mental health should be launched in all countries. Well-designed awareness and education campaigns may help reducing stigmatization and discrimination by promoting mental and physical health within the population" [4] [5] [6].

Therefore, it is demanding addressing, although briefly, the subject of suicide among pre- and school-age adolescents. This subject is of great concern, since it generates enormous emotional, family and social impact, and is subject to myths and taboos, mainly by the media and by the authorities, who fear the Werther Effect (suicide waves taking place due to imitation or induction). The Sorrows of Young Werther is a book written in 1774 [14] by German writer Johann Wolfgang von Goethe, when he was 25 years old. Goethe's novel, whose protagonist commits suicide after a romantic relationship ended, had a disastrous effect that led to many juvenile suicide cases throughout Europe in the eighteenth century.

The subject "suicide" in Brazil strongly lacks information based on scientific and educational approaches. Even scientific and official statistics are subject to a bias that distorts reality, to the underreporting of cases in official records 
whether through omission, taboo or other factors-, as well as to the non-clarification of para-suicide situations, which are related to accidents and to extremely risky and potentially lethal behaviors in children and adolescents who do not show clear intention to commit suicide.

According to data from the Map of Violence, Brazilian Youth, Waiselfisz (2014) [15], suicide-related deaths among young people and adolescents, from 1980 to 2012, were the third mortality cause deriving from external reasons among young people in Brazil; it was second to deaths by homicides and transport accidents.

Nowadays, moral, verbal, sexual, virtual and even corporal aggression, the so-called Bullying, is very common among teenage students. Bullying has motivated educators and researchers to study the causes behind human trivialization, as well as behind the collective loss of some social values and of the meaning given to the word "respect" between colleagues [5]. The expansion of such phenomenon, the cyberbullying among young students, has reached increasing proportions and repercussions. Cyberbullying is characterized when one or more individuals use electronic means to expose, embarrass, assault, inflict injury or discomfort, humiliate, scare or cause feelings such as insecurity and despair in the individual targeted by the aggression. These actions may happen through emails, chat rooms, mobile phones, instant messaging, and online voting booths. There is scientific evidence indicating that $20 \%$ to $40 \%$ of the adolescents will experience at least one cyberbullying event, as well as that this rate is increasing [16].

Generation Z [17] is the sociological name given to people born between 1990 and 2010, who are also called digital natives. This generation is characterized by the multiplicity of tasks: they are able to study while listening to music, or simultaneously watch TV, access social networks, talk on the cell phone, search information on the Internet, and send instant messages, among other activities such as eating.

Accordingly, it is worth highlighting the concepts and ideas by Zygmunt Bauman [18], who subjected romantic relationships and some peculiarities of the "liquid modernity" to a simpler analysis close to the daily life. We live liquid times, nothing is made to last or is solid. Relationships slip through our fingers like water.

According to Bauman [18] [19], the society preceding postmodernity comprised community-developed individuals. Since community precedes individuals, it allows developing the sense of belonging, through parental and kinship affective bonds and affinities, which are reliable and unbreakable. Thus, individuals form their identity based on bonds that allow developing basic confidence, although in a society marked by such a strong "disposability" that affinities become rare and confusing. Paradoxically, postmodern society significantly changed this paradigm, which is nowadays fragmented, focused on the individual and on network relationships basically characterized by two immediate possi- 
bilities, namely: connecting and disconnecting oneself in a serial and automatic way.

If one considers school as the extension and expression of such reality, it is worth mentioning About Territories and Sense of Place [20] by Holzer. "We are beings-in-situation; being in situation means presenting and unveiling the world based on our individuality. Places, in turn, only exist because humans share experiences. Geographicity, which expresses the materiality of the geographical space, is shared in our everyday experiences with the sense of place, which, in turn, expresses exactly the dialogical relationship of beings in motion with places and paths".

For most adolescents, electronic communication is part of the pro-social behavior aimed at developing and keeping affective relationship and friendship networks through which they rehearse and learn to introduce themselves to others, as well as to adjust their self-presentation according to the reactions of others. The sense of intimacy developed in these relationships enables self-presentation and self-revelation, as well as their consequent adaptations and maladjustments. In addition, feedbacks allow individuals rehearsing and validating their social identities [21]. Thus, several studies suggest that self-presentation and self-disclosure increasingly happen on the internet in detriment to the one-to-one communication [22] [23].

The adolescent education process comprises a series of complex emotional experiences. Family and school walk together and constitute the basic social core of meaningful experiences, which may later favor or disfavor the development of citizen human beings [24] [25].

School is the society microcosm where adolescents prepare themselves to deal with situations they will face "in the world outside". Students also develop (or not) several skills at school such as listening, negotiating, giving away, participating, cooperating, persevering, and developing self-discipline and responsibility [13] [26] [27] [28]. These skills are essential to human success, which cannot be just understood as professional and financial success, but also as success in all spheres of life, mainly when it comes to Mental Health [29] [30].

\section{Mental Health Education and Transversal Themes}

Brazilian education has been facing deep and complex transformations in the structure of educational institutions, as well as in the educational goals and teachers' performance. One of these transformations lies on the inclusion of Transversal Themes in school curricula through the National Curricular Parameters (NCPs) for Secondary School. These Transversal Themes address relevant topics such as ethics, cultural and sexual diversity, environment and health [31] [32].

The Law on Brazilian Education Guidelines and Bases (N. 9394), along with the NCPs in Brazil [33], allowed the theme "health" to gain space in schools as a Transversal Theme. It enabled addressing several aspects inherent to individual 
and collective health processes, which may be approached in all disciplines; the way of understanding and inserting the themes may happen in different ways [34].

Although the NCP proposal recommend transversality between contents, many teachers working in schools were not introduced to Transversal Theme-related contents during their training. In addition, "the tradition issue follows each field, fact that makes it difficult incorporating other ways to work with the contents" [35].

Health Education (HE) [36] is the most efficient way to promote the adoption of healthy behaviors and to modify the harmful ones [36]. The access to information, and the understanding of mental health contents by children, adolescents and teachers in the school environment, allow understanding and using information in the care of one's own health, as well as stimulating cognitive and social skills to promote mental health and prevent mental health-related issues.

Thus, it is essential raisingschool community awareness and including mental health education contents in the teaching of young people and adolescents [37]. In addition, since one of the goals of school education is to train citizens who are aware of their rights and duties, health education becomes essential to the health responsibility and autonomy process [38].

The school system is a strategic and privileged place for the implementation of public health policies focused on young people. It stands out as the main core for mental health promotion and for the prevention of mental health-related issues in children and adolescents, since it enables developing risk protection and reduction factors. Therefore, promoting mental health education means, above all, promoting children and young people by assuring their fundamental rights in order to generate happy people able to contribute to collective well-being [39].

The Canadian Curriculum Guide for Mental Health at School (Teen Mental Health) is an example of mental health approach focused on students, since it incorporates mental health literacy in the school curriculum. Scientific evidences gathered through the project were effective in helping educators and students to assimilate knowledge and change mental health-related attitudes [39].

In the United States, the PATHS-Promoting Alternative Thinking Strategies-has implemented a specific curriculum to help promoting knowledge about emotions, building positive relationships, and developing problem-solving skills. Results show that the program stimulates cognition, planning capacity, working memory, and impulse control, among others [39].

It is worth mentioning the following projects developed in Brazil: Comunidade Aprender Criança (Child Learning Community) linked to the Glia Institute, University of Ribeirão Preto, SP, which developed the Project Atenção Brasil: Educando com Ajuda das Neurociências (Attention Brazil: Educating through Neurosciences). Another initiative lies on Projeto Cuca Legal (Healthy Brain Project) linked to the Federal University of São Paulo, which, based on studies, develops educational mental health promotion and prevention strategies to be implemented to the school environment through an approach focused on 
supporting and empowering educators and other professionals working in the education context [39].

\section{Materials and Methods}

\subsection{Population and Sample}

The herein investigated population comprised 94 volunteer students enrolled in $1^{\text {st }}, 2^{\text {nd }}$ and $3^{\text {rd }}$ grades of the Polytechnic School, a federal public high school linked to the Federal University of Santa Maria (CPUFSM-Colégio Politécnico da Universidade Federal de Santa Maria).

\subsection{Data Collection Instrument}

The current study used the Self-Reporting Questionnaire (SRQ) developed by Harding et al. [40] as instrument to identify psychiatric disorders at primary care level. The SRQ, which was adopted by WHO [4] and validated in Brazil by Mari and Willians [41], comprises 20 questions focused on identifying minor psychiatric or mental disorders (MPDs).

Minor Psychiatric Disorders (MPDs) or Minor Mental Disorders (MMDs) present prominent symptoms that lead to comparable functional and/or intellectual impairment or even worse than well-established chronic conditions [41] [42], although they do not meet the formal criteria to diagnose depression and/or anxiety according to the DSM-IV (Diagnostic and Statistical Manual of Mental Disorders, $4^{\text {th }}$ Edition) and to the ICD-10 (International Classification of Diseases, $10^{\text {th }}$ Revision).

The number of population-based epidemiological investigations, mainly in the mental health field, is still not very expressive in Brazil. For an individual to be considered a possible mental health case, he/she must score seven (7) or more affirmative answers, worth one point each, in the SRQ-20; score 7 is the cut-off point and it was set based on the determination of sensitivity, specificity, and positive and negative predictive values recorded in other samples. This cut-off point allows forming two groups, one composed of individuals most likely to develop common mental disorders and the other one composed of individuals prone not to develop them.

\section{Results and Discussion}

Ninety-four (94) out of 115 high school students enrolled at the Polytechnic School of Federal University of Santa Maria accepted to participate in the study and responded to the SRQ-20 [4] [41]. The sample (Graph 1) comprised 42 girls and 52 boys (all single), whose ages ranged from 12 to 19 years. Seven (7) out of 30 students enrolled in the $1^{\text {st }}$ grade scored above 7 , as well as 14 out of $302^{\text {nd }}$ grade students and 10 out of $343^{\text {rd }}$ grade students who answered the questionnaire. Thus, 31 out of 94 students in the sample scored above the cut-off point set for the SRQ-20 [4] [41].

If one takes into consideration the parameter stipulated to apply the SRQ-20 


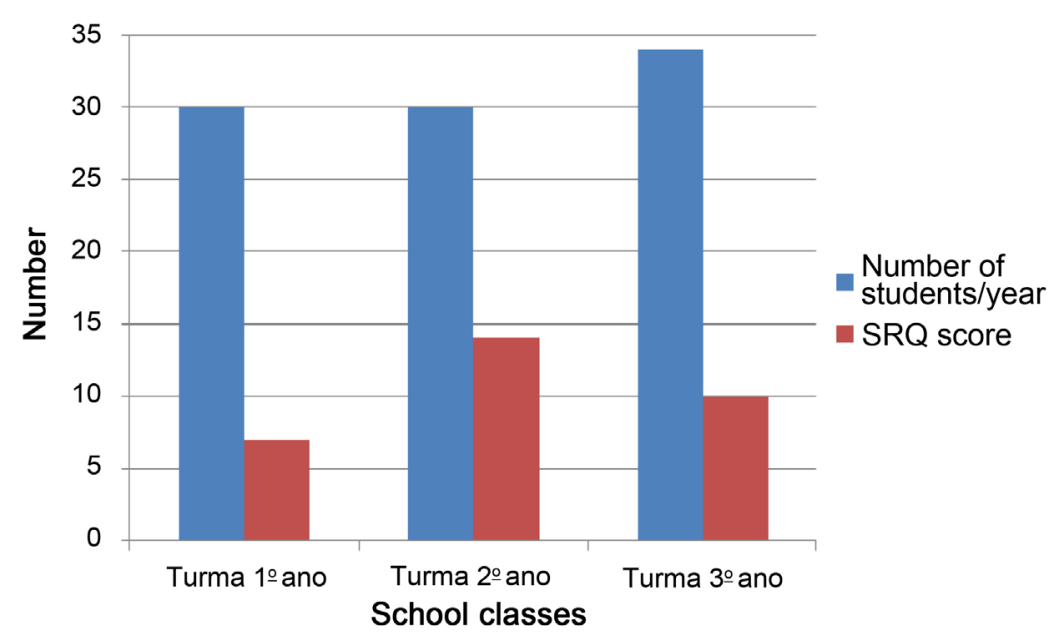

Graph 1. Total number of students per grade enrolled in the Polytechnic High School, Federal University of Santa Maria (CPUFSM), who answered the SRQ-20, and number of students who scored equal to or higher than 7 in the SRQ-20. Source: Prepared by the author.

[4] [41], it was possible seeing that approximately $23.33 \%$ of the students in the $1^{\text {st }}$ grade, $46.66 \%$ of the students in the $2^{\text {nd }}$ grade and $29.41 \%$ of the students in the $3^{\text {rd }}$ grade, i.e., $32.98 \%$ of the sample, scored above the cut-off point. Thus, $32.98 \%$ of the students presented some psychiatric and emotional suffering level and may be considered as having some type of Minor Psychological Disorder (MPD) or Minor Mental Disorder (MMD) able to affect their quality of life and mental health, as well as to impair their cognitive functioning, learning and performance in such an important and decisive stage of their psychosocial, intellectual and academic development, with potential risk of disrupting and/or significantly compromising their overall development.

These results consistently correlate with results found in previous studies, which showed that children and adolescents suffering from mental disorders are unable to appropriately use resources in order to identify and treat such disorders; therefore, they are more exposed to the risk of alcohol and drug abuse, low school performance, violent and criminal activities, idealization and suicidal thoughts [43].

The Chi-square $\mathrm{x} 2$ test (Graph 2) was performed, but it did not present significant results $(\mathrm{p}=0.3169)$, i.e., there was no correlation between the high school grade and the students' score in the SRQ-20 [44].

According to Estanislau and Bressan [39], young people with mental disorders present low school performance and quit school. Thus, the lack of reliable information and of specialized guidance causes insecurity, which is a relevant factor to the distortion of the teacher's view, who end up seeing mental disorders where there is none, and vice versa.

According to Brazilian epidemiological studies, $10 \%$ to $20 \%$ of children and adolescents present some psychiatric and mental suffering level. In addition, 1 in 8 young people belonging to the age group 7-to-14 years enrolled in schools in 


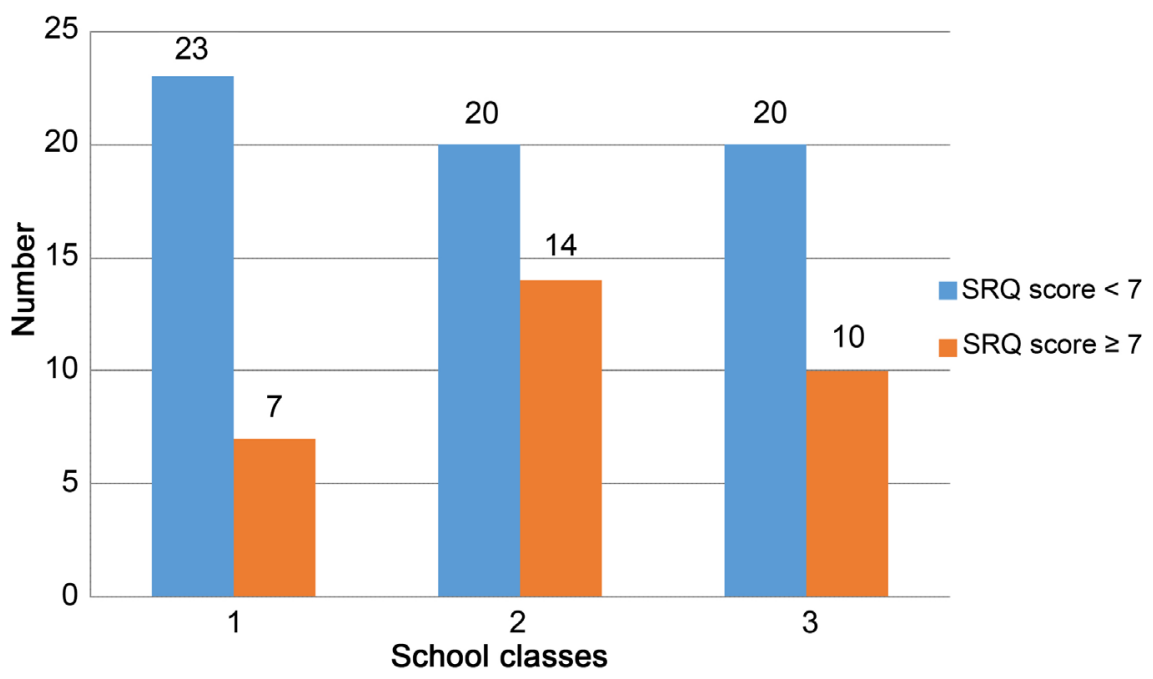

Graph 2. The relation between high school grades and scores achieved by students who answered the SRQ-20. Source: Prepared by the author.

Southeastern Brazil have some type of difficulty that justifies the need for attention by mental health professionals [12] [45].

It is known that the impact caused by psychiatric disorders on peoples' lives is the most detrimental among all the health issues affecting the 10-to-24-year-old population, mainly school children and adolescents; these health issues may be measured through the Global Burden of Disease Study. The situation is particularly alarming in Brazil due to the continental size of the country and to its socio-cultural diversity.

A recent study conducted a systematic review of electronic databases on the prevalence of mental disorders among children and adolescents over the past 13 years (including the period after the WHO [6] report was published). The authors concluded that, in a universe of 7040 articles, the most often disorders affecting children and adolescents were depression, anxiety, attention deficit and hyperactivity, substance use-related disorders and conduct disorders, which showed varying prevalences [46].

In our field, it is worth highlighting the Attention Brazil Project [2], which was developed through a partnership involving the following institutions: University of São Paulo, Medical School of São José do Rio Preto (SP), La Sapienza Institute in Rome (ITA) and Albert Einstein College of Medicine (USA). The study assessed through questionnaires and research protocols applied to the parents and teachers of 5961 children and adolescents (predominantly from public schools) in five Brazilian regions, including 16 states and 81 small-, medium- and large-sized cities; 11 of them were capitals.

The study assessed demographic, developmental, gestational, habit-related and other aspects, as well as applied the worldwide used Strengths and Difficulties Questionnaire (SDQ), which was validated in Brazil [47].

Results showed that $10 \%$ to $15 \%$ of children and adolescents, which were as- 
sessed through questionnaires answered by parents and teachers, were likely to suffer from some issue able to affect their mental health. The rates varied within this range depending on the region in the country; the national mean was $12.7 \%$ [2].

The information and knowledge about mental health in the school community are relevant, since they allow identifying symptoms that require referring individuals in order to be assessed by a mental health team, fact that may enable early interventions. According to Puura et al. [48] "teachers are in the ideal position to observe signs of irritability, social isolation and decreased school performance". Training the school community (teachers/students) is a protective factor that reinforces pro-mental health development actions, knowledge acquisition and application, attitudes and competences necessary to understand and manage emotions, as well as to set and keep healthy relationships [48].

The research data analysis and the review of the literature about the herein proposed theme allowed planning the elaboration of Distance Learning Educational Modules using resources from the virtual learning environment, Moodle Platform (Modular Object Oriented Dynamic Learning Environment) [49], offered to high school teachers and focused on social and emotional training, promotion, prevention and learning (SEL-Social and Emotional Learning). SEL [39] "is understood as the process concerning the acquisition and reinforcement of social emotional skill (SES), i.e., skills able to help individuals to deal with themselves, to relate to others, and to perform tasks (study, work, etc.) in a competent and ethical way".

The topics suggested in the present proposition, as well as the dynamic activities and practices, will be based on the biopsychosocial model, without involving the medicalization of the issue (the term medicalization refers to the process wherein non-medical issues, which are eminently of social and political origin, are transformed into medical ones; in other words, trying to find the causes and solutions to such issues in the medical field). It is based on a concept of medical science that addresses the health-disease process as focused on the individual, thus favoring the biological, organicist approach [50].

Thus, the suggested actions would prioritize promoting mental health education based on the humanistic perspective, encouraging receptive and welcoming school environments, as well as promoting healthy, trustworthy and potentially creative school interpersonal relationships among students, teachers and school community professionals.

In the broader perspective, the proposed actions promote empowerment, which implies the achievement of freedom, progress and the overcoming of the subordination state (economic, physical, psychological dependence, etc.) by those who empower themselves (active subjects in the process), rather than a simple donation or transference motivated by benevolence [51]. This process, which is carried out by the individuals themselves, promotes changes and actions that help them evolving and becoming stronger as subjects involved in the 
reciprocal mental health teaching and education process and allow inserting the topic "mental health" as transversal theme in science education contents [52]. This empowerment phenomenon is a reciprocal growth process based on information, knowledge and on the acquisition of skills, competencies and autonomy.

Health education is defined by WHO [53] as "any combination of learning experiences designed to help individuals and communities to improve their health by increasing their knowledge or by influencing their attitudes" [53].

It is worth emphasizing the relevance of the topic "mental health education" inserted in transversal themes focused on an interdisciplinary context, which involves different knowledge and science fields such as science education, health and collective health education, pedagogy, psychology, as well as related and complementary fields.

\section{Conclusions}

The results in the current study showed that $32.98 \%$ of the 94 research participants presented some psychiatric and emotional suffering level compatible with some form of Minor Psychiatric or Mental Disorder (MPD/MMD). These data become worrisome when one knows the consequences from this type of disorder during adolescence and youth, since they are significant transition stages in the lives of individuals, whose body undergoes a maturation process, and whose development and well-being may be compromised.

It is necessary to develop programs aimed at increasing the knowledge about mental health, both for educators and for children and adolescents, since childhood and adolescence are privileged periods for the acquisition of models and references to incorporate behaviors in the transition towards adulthood. Schools are privileged places for the implementation of programs, not only because they are places where young people spend most of their time, but also because they are privileged places for the acquisition of health-promoting knowledge and skills. Although mental health education remains a poorly debated subject, it implies knowledge focused on actions able to improve the health of young people and their peers.

During the development of the current study, it was possible seeing several successful initiatives in Brazil and in other countries, the fact leads us to a short-term perspective concerning the elaboration of a Folder containing theoretical reference and links to be used by teachers and students, since it is written in an accessible language, which can be used and applied to the school environment.

Therefore, it is herein understood that mental health education should become a fundamental principle of school health programs, since it promotes the adoption of healthy behaviors in a humanistic perspective that aggregates knowledge and concepts such as the promotion, prevention, acquisition and empowerment of skills able to reflect on and affect the daily lives of students and of the school community. 


\section{Conflicts of Interest}

The authors declare no conflicts of interest regarding the publication of this paper.

\section{References}

[1] Roehrs, H., Maftum, M.A. and Zagonel, I.P.S. (2010) Adolescência na percepção de professores do ensino fundamental. Revista da Escola de Enfermagem, USP, 44, 421-428. https://doi.org/10.1590/S0080-62342010000200026

[2] Arruda, M.A., et al. (2010) Projeto Atenção Brasil: Saúde Mental e desempenho escolar em crianças e adolescentes brasileiros. Análise dos resultados e recomendações para o educador com base em evidências científicas. Ed. Instituto Glia, Ribeirão Preto, SP.

[3] Da Silva e Silva, A. (2015) A interface família escola e saúde mental na infância e adolescência.

[4] WHO World Health Organization (1994) Expert Committee on Mental Health. Geneva.

[5] Bassols, A.M., et al. (2003) Saúde mental na escola-uma abordagem multidisciplinar. Editora Mediação, Volume I, 134 p.

[6] WHO World Health Organization (2001) Mental Health: New Understanding, New Hope the World Health Report.

[7] UNICEF (2011) Fundo das Nações Unidas para a Infância. Situação Mundial da Infância 2011: Adolescência uma fase de oportunidades.

[8] Eisenstein, E. (2005) Adolescência: Definições, conceitos e critéri. Adolesc Saude, 2, 6-7.

[9] Erikson, E.H. and Erikson, J. (1998) O ciclo da vida completo. ArtesMédicas, Porto Alegre, $112 \mathrm{p}$.

[10] Erikson, E.H. (1987) Infância e Sociedade. 2nd Edition, Zahar editors, Rio de Janeiro, $128 \mathrm{p}$.

[11] Rabello, E.T. and Passos, J.S. (2015) Erikson e a teoria psicossocial do desenvolvimento. http://www.josesilveira.com

[12] Paula, C.S., Duarte, C.S. and Bordin, I.A. (2007) Prevalence of Mental Health Problems in Children and Adolescents from the Outskirts of Sao Paulo City: Treatment Needs and Service Capacity Evaluation. Revista Brasileira de Psiquiatria, 29, 11-17. https://doi.org/10.1590/S1516-44462007000100006

[13] Azambuja, C.R., et al. (2014) Association between Physical Activity Level and Body Image in College Students. In: International Workshop and Exhibition about Physical Activity in Times of Major Sporting Events, ILSI Brasil/FSP USP, São Paulo.

[14] Goethe, J.W. (2001) Os Sofrimentos do Jovem Werther. Coleção L\&PM Pocket, Porto Alegre, $208 \mathrm{p}$.

[15] Waiselfisz, J.J. (2014) Mapa da Violência 2014: Jovens do Brasil. CEBELA-FLACSO.

[16] Bottino, S.M.B. (2015) Repercussões do Cyberbullying na saúde mental dos adolescentes. Revista debates em psiquiatria, 5, 20-26. https://doi.org/10.25118/2236-918X-5-2-4

[17] IBOPE. Instituto Brasileiro de Opinião Pública e Estatística (2015) Gerações Y e Z: Juventude digital.

[18] Bauman, Z. (2004) Amor Líquido-Ed. Zahar Nacional. 192. 
[19] Bauman, Z. (2015) Fronteiras do pensamento. http://www.fronteiras.com/entrevistas/vivemos-o-fim-do-futuro

[20] Holzer, W. (2013) Sobre Territórios e Lugaridades. Cidades-Revista Científica, 10.

[21] Valkenburg, P.M. and Peter, J. (2011) Online Communication among Adolescents: An Integrated Model of Its Attraction, Opportunities, and Risks. Journal of Adolescent Health, 48, 121-127. https://doi.org/10.1016/j.jadohealth.2010.08.020

[22] Davis, K. (2010) Coming of Age Online: The Developmental Underpinnings of Girls' Blogs. Journal of Adolescent Research, 25, 145-171. https://doi.org/10.1177/0743558409350503

[23] Schmitt, K.L., Dayanim, S. and Matthias, S. (2008) Personal Homepage Construction as an Expression of Social Development. Developmental Psychology, 44, 496-506. https://doi.org/10.1037/0012-1649.44.2.496

[24] Cury, C.R. and Golfeto, J.H. (2003) Strengths and Difficulties Questionnaire (SDQ): A Study of School Children in Ribeirão Preto. Revista Brasileira de Psiquiatria, 25, 139-145. https://doi.org/10.1590/S1516-44462003000300005

[25] Benetti, S.P.C., et al. (2007) Adolescência e saúde mental: Revisão de artigos brasileiros publicados em periódicos nacionais. Caderno de Saúde Pública, 23, 1273-1282. https://doi.org/10.1590/S0102-311X2007000600003

[26] Williams, S.B., et al. (2009) Screening for Child and Adolescent Depression in Primary Care Settings: A Systematic Evidence Review for the US Preventive Services Task Force. Pediatrics, 123, e716-e735.

[27] Levitt, J.M., et al. (2007) Early Identification of Mental Problems in Schools: The Status of Instrumentation. Journal of School Psychology, 45, 163-191.

https://doi.org/10.1016/j.jsp.2006.11.005

[28] Ferreira, M.C.T. and Marturano, E.M. (2002) Ambiente familiar e os problemas do comportamento apresentados por crianças com baixo rendimento escolar. Psicologia: Reflexão e Crítica. https://doi.org/10.1590/S0102-79722002000100005

[29] Ford, T., Goodman, R. and Meltzer, H. (2003) The British Child and Adolescent Mental Health Survey 1999, the Prevalence of DSM-IV Disorders. Journal of American Academy of Child and Adolescent Psychiatry, 42, 1203-1211. https://doi.org/10.1097/00004583-200310000-00011

[30] Roberts, R.E., Roberts, C.R. and Xing, Y. (2007) Rates of DSM-IV Psychiatric Disorders among Adolescents in a Large Metropolitan Area. Journal of Psychiatric Research, 41, 959-967. https://doi.org/10.1016/j.jpsychires.2006.09.006

[31] Matos, M. and Sardinha, S. (1999) Estilos de vida activos e qualidade de vida. Ediçoes FMH, Lisboa, 163-181.

[32] Brasil. Secretaria de Educação Fundamental (2015) Parâmetros Curriculares Nacionais: Introdução aos parâmetros curriculares nacionais. MEC/SEF, Brasília, 1997, 126 p. http://portal.mec.gov.br/seb/arquivos/pdf/livro01.pdf

[33] Brasil (2015) Casa Civil. Subchefia para Assuntos Jurídicos. Lei no 9.394-Lei de Diretrizes e Bases da Educação Nacional, de 20 de dezembro de 1996.

http://www.planalto.gov.br/ccivil 03/leis/19394.htm

[34] Darido, S.C. (2012) Cadernos de Formação: Conteúdos e Didática de Educação Física. São Paulo: Cultura Acadêmica, 1, 176.

[35] Darido, S.C., et al. (2001) Educação Física, a formação do cidadão e os parâmetros curriculares nacionais. Revista Paulista de Educação Física, 15, 17-32.

[36] Gomes, J.P. (2009) As Escolas Promotoras de Saúde: Uma via para promover a 
saúde e a educação para a saúde da comunidade escolar. Educação, Pontifícia Universidade Católica do Rio Grande do Sul-Porto Alegre, Brasil, 32, 84-91.

[37] Loureiro, L.M.J., et al. (2012) Literacia em saúde mental de adolescentes e jovens: Conceitos e desafios. Revista de. Enfermagem Referência, III Série, 6, 157-166. https://doi.org/10.12707/RIII11112

[38] Leonello, V.M. and L'abbate, S. (2006) Educação em saúde na escola: Uma abordagem do currículo e da percepção de alunos de graduação em pedagogia. Interface-Comunicação, Saúde, Educação, 10, 149-166. https://doi.org/10.1590/S1414-32832006000100011

[39] Estanislau, G.M. and Bressan, R.A. (2014) Saúde Mental na Escola: O que os educadores devem saber. Porto Alegre, Artmed, 277.

[40] Harding, T.W., et al. (1980) Mental Disorders in Primary Health Care: A Study of Their Frequency and Diagnosis in Four Developing Countries. Psychological Medicine, 10, 231-241. https://doi.org/10.1017/S0033291700043993

[41] Mari, J.J. and Williams, P. (1986) A Validity Study of a Psychiatric Screening Questionnaire (SRQ-20) in Primary Care in the City of São Paulo. Brazilian Journal Psychiatry, 148, 23-26. https://doi.org/10.1192/bjp.148.1.23

[42] Mello, M.F., Mello, A.A.F. and Kohn, R. (2007) Epidemiologia da saúde mental no Brasil. Artmed, Porto Alegre, 207 p.

[43] Carvalho, P.D., et al. (2011) Prevalência e fatores associados a indicadores negativos de saúde mental em adolescentes estudantes do ensino médio em Pernambuco. Brasil. Rev. Bras. Saúde Matern. Infant., 11, 227-238.

[44] Triola, M.F. (2005) Introdução à Estatística. 9. ed., LTC, Rio de Janeiro, 682 p.

[45] Moraes, C. (2008) Carta aos editors "força-tarefa brasileira de psiquiatrias da infância e adolescência”. Revista Brasileira de Psiquiatria, 30, 290-301. https://doi.org/10.1590/S1516-44462008000300021

[46] Thiengo, D.L., Cavalcante, M.T. and Lovisi, G.M. (2014) Prevalência de transtornos mentais entre crianças e adolescentes e fatores associados: Uma revisão sistemática. Jornal Brasileiro de Psiquiatria (UFRJ. Impresso), 63, 360-372. https://doi.org/10.1590/0047-2085000000046

[47] Goodman, R. (1999) The Extended Version of the Strengths and Difficulties Questionnaire as a Guide to Child Psychiatric Caseness and Consequent Burden. Journal of Child Psychology and Psychiatry, 40, 791-801. https://doi.org/10.1111/1469-7610.00494

[48] Puura, K., et al. (1998) Children with Symptoms of Depression-What Do the Adults See? Journal of Child Psychology and Psychiatry, 39, 577-585. https://doi.org/10.1017/S0021963098002418

[49] Moodle (2015) Modular Object Oriented Dynamic Learning Environment. https://moodle.org

[50] Collares, C.A.L. and Moysés, M.A.A. (1994) A Transformação do Espaço Pedagógico em Espaço Clínico-A Patologização da Educação. Publicação: Série Idéias, 23, 25-31.

[51] Freire, P. (1986) Medo e ousadia: Cotidiano do professor. 5th Edition, Paz e Terra, Rio de Janeiro, $312 \mathrm{p}$.

[52] Roso, A. and Romanini, M. (2014) Empoderamento individual, empoderamento comunitário e conscientização: Um ensaio teórico. Psicologia e Saber Social, 3, 83-95. https://doi.org/10.12957/psi.saber.soc.2014.12203

[53] WHO World Health Organization (2013) Health Education. World Health Organization, Geneva. 


\section{Appendix (Abstract and Keywords in Português)}

Avaliação Com Alunos De Uma Escola Pública: Promoção E Prevenção Em Saúde Mental No Ensino Médio

\section{RESUMO}

O estudo objetivou detectar alterações emocionais e de saúde mental que causem sofrimento psíquico suficientes para interferir no processo de aprendizagem em estudantes do ensino médio. Participaram do estudo alunos dos três anos de uma escola pública federal de Santa Maria, RS, Brasil. Dos 115 alunos, 94 responderam o Self Report Quetionnaire-SRQ-20, instrumento da Organização Mundial de Saúde, OMS utilizado mundialmente em nível de atenção primária para identificar Transtornos Mentais ou Psíquicos Menores (TMM/TPM). Destes, 32.98\% atingiram escore suficiente de sofrimento psíquico. Propõem-se estimular o conhecimento em saúde mental e capacitação contínua dos educadores através de Módulos Educativos de Promoção, Prevenção e Aprendizagem Socioemocional contextualizados nos conteúdos do ensino de ciências, bem como o nível de informação dos alunos sobre o tema. É a escola, o espaço-território estrategicamente privilegiado para essas ações, onde crianças e adolescentes passam a maior parte do tempo, oportunizando a aquisição de saberes e o empoderamento de competências promotoras de saúde mental.

\section{Palavras-Chave}

Adolescentes, Saúde Mental na Escola, Educação em Ciências, Ações preventivas 